\title{
Chromosome aberrations in a large series of spontaneous miscarriages in the German population and review of the literature
}

Jutta Jenderny

\begin{abstract}
Background: In a review of the literature in 2000 the different cytogenetic aspects of spontaneous miscarriages were well documented. This review also included the spontaneous miscarriage results of one large German study published in 1990. However, to our knowledge there are no new data on spontaneous miscarriages in the German population. Therefore, the aim of the present retrospective large study was to find out the incidence and types of chromosome aberrations in an unselected series of spontaneous miscarriages in the German population, and whether our more recent results were different to data published previously. In case of culture failure we implemented a quantitative fluorescent polymerase chain reaction (QF-PCR) for chromosomes 13, 18, 21, X and Y.

Results: In the present German retrospective study cytogenetic analysis (CA) was attempted on 534 spontaneous miscarriages between weeks 7 and 34 of gestation, being successful in 73\% (390/534) of them. Two hundred and thirty-seven of the cases $(61 \%, 237 / 390)$ were chromosomally abnormal. Trisomy was the most common chromosome aberration and accounted for 53\% (125/237) of the aberrant karyotypes. A multiple aneuploidy was observed in 7\% (17/237) of the aberrant karyotypes. Chromosomes 16, 22, 15 and 21 were found most frequently involved in aneuploidies. Fifty-four cases $(23 \%, 54 / 237)$ with a polyploidy were found in the present study. Single unbalanced structural chromosome aberrations accounted for $4 \%$ (10/237) of the aberrant karyotypes. Eleven samples (5\%, 11/237) displayed a variety of numerical and/or structural chromosome aberrations. One hundred and forty-four spontaneous miscarriages $(27 \%, 144 / 534)$ failed to grow in culture. A total of 27 cases were analysed by QF-PCR for chromosomes $13,18,21, X$ and $Y$, being informative in all cases.

Conclusion: In our German retrospective large study of spontaneous miscarriages, the incidence and types of chromosome aberrations by CA are within the reported range of other studies published previously before and after 2000. Therefore, we can conclude that cytogenetic aspects of spontaneous miscarriages have not changed over the years. Additionally 8 of 27 cases (30\%) without cell growth showed a numerical chromosome aberration by QF-PCR. Therefore QF-PCR played an important role as a supplementary test when culture failure occurred.
\end{abstract}

Keywords: Chromosome aberrations, Cytogenetic analysis, Cytogenetics, Karyotyping, Miscarriage, QF-PCR

\section{Background}

Of all clinically recognized pregnancies, about $10 \%-16 \%$ end in early spontaneous miscarriages $[1,2]$. The overall prevalence of pregnancy losses is generally assumed to be much higher. Using an immunoradiometric assay to detect increased hCG levels near the expected time of

Correspondence: jenderny@labor-lademannbogen.de

Humangenetik, Labor Lademannbogen, Lademannbogen 61-63, DE-22339 Hamburg, Germany

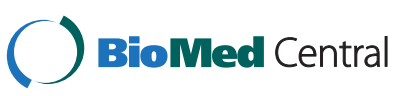

implantation, $22 \%$ of pregnancies were ended before clinically detected [3].

Many factors can cause embryo losses, but it is well known from previous large studies ( $>500$ cases) that up to $57 \%$ of spontaneous miscarriages result from chromosome aberrations [4-6]. Therefore cytogenetic analysis (CA) of the aborted sample is highly recommended and any result will facilitate counselling for affected couples [7]. In a review of the literature in 2000 the different cytogenetic aspects of spontaneous miscarriages by $\mathrm{CA}$ were well summarized in detail [8]. This review also included the 
CA results of a large German spontaneous miscarriage study published in 1990 [4]. However, new CA data on spontaneous miscarriages in the German population are rare. Therefore, the aim of the present retrospective large study was to find out the incidence and types of chromosome aberrations in an unselected series of spontaneous miscarriages in the German population, and whether our more recent CA results were different to data previously published.

CA of spontaneous miscarriages has a significant failure rate when the tissue sample (chorionic villi is the tissue of choice) is autolysed or otherwise not suitable for standard cell culture. Since 2000, quantitative fluorescent polymerase chain reaction (QF-PCR) analysis has been well established in our laboratory [9-11], and we have confirmed the clinical utility of QF-PCR on prenatal chorionic villi [10]. To improve the success rate of CA on spontaneous miscarriages in our laboratory, a supplemental diagnostic assay was therefore considered. We implanted QF-PCR to detect major clinically significant numerical chromosome aberrations in spontaneous miscarriages, and in case of cell growth failure, molecular analysis for chromosomes $13,18,21, \mathrm{X}$ and $\mathrm{Y}$ was performed on demand.

\section{Methods}

A total of 534 spontaneous miscarriage cases were collected between 2002 and 2013, most of them were referred to our laboratory without any clinical data. All the samples consisted of chorionic villi obtained after surgical evacuation between weeks 7 and 34 of gestation age. Uncertain materials were histologically examined by the pathologists in our laboratory. Selected chorionic villi were examined to exclude maternal deciduas remains. The carefully dissected chorionic villi samples were cultured and karyotyped according to a standard procedure. A nearly directpreparation of chorionic villi was not carried out, because this method is too labour-intensive in a routine diagnostic laboratory. At least 11 G-banding metaphases were analysed. The G-banding quality was between 400 to 500 bphs. The aberrations and karyotypes were classified according to the International System for Human Cytogenetic Nomenclature 2013 (ISCN 2013) [12]. A mosaicism was defined according to the ISCN 2013 definition of a clone: loss of a chromosome must be detected in at least three cells, gain of a chromosome and/or a structural chromosome aberration must be present in at least two metaphases. In case of cell growth failure QF-PCR was performed on demand. Between 2002 and 2011 genomic DNA was extracted from the cells of the tissue culture without cell growth using a QIAamp blood kit (Qiagen, Germany). From 2012 onwards genomic DNA was extracted from a small piece of the chorionic villi within the first 7 days after sample collection using a QIAamp blood kit (Qiagen,
Germany). Extracted DNA was stored frozen at minus $20^{\circ} \mathrm{C}$ until the decision of the patient whether a QF-PCR investigation should be carried out. For the detection of a clinically significant numerical chromosome aberration the conditions of the QF-PCRs with 13 selected specific markers were described previously [9]. From 2012 onwards, we used the Devyser Compact v3 kit with 26 selected specific markers according to the instructions of the company (Devyser AB, Stockholm, Sweden).

\section{Ethical approval and consent}

These studies were performed on anonymized samples received in our laboratory and thus were exempted from the requirement for consent by an opinion for the Western Institutional Review Board.

\section{Results}

CA was exclusively done from carefully dissected chorionic villi. CA from unidentified tissue and from induced abortions sent to the laboratory for confirmation of abnormal results obtained from CVS or amniocenteses were not included in the study. CA was attempted on 534 spontaneous miscarriages, being successful in 73\% (390/534) of the samples. Of them, $42 \%(164 / 390)$ of the cases showed a male karyotype and 58\% (226/390) of the cases showed a female karyotype. A normal male karyotype was observed in 74 of the cases and a normal female karyotype in 79 of the cases, resulting in a male-to-female sex ratio of 0.94 . Two hundred and thirty-seven $(61 \%, 237 / 390)$ of the cases were chromosomally abnormal. One hundred and forty-four spontaneous miscarriages $(27 \%, 144 / 534)$ failed to grow in culture. Of them, a total of 27 cases were analysed by QF-PCR. QF-PCR analysis for chromosomes 13, $18,21, \mathrm{X}$ and $\mathrm{Y}$ was informative in all cases. An uninformative QF-PCR pattern for a single chromosome was not observed.

Table 1 shows the incidence and types of chromosome aberrations by $\mathrm{CA}$ in our retrospective large German study and reviewed other studies published previously. Table 2 lists the different CA and QF-PCR results obtained in the present study.

\section{Trisomy}

$C A(n=125)$

Trisomy was the most common chromosome aberration and accounted for $53 \%(125 / 237)$ of the aberrant karyotypes. Of them, $89 \%(111 / 125)$ of the cases were pure trisomic, $11 \%(14 / 125)$ of the cases showed mosaicism. The most frequent type was trisomy 16 (25 cases), followed by trisomy 22 (21 cases), 15 (19 cases) and 21 (10 cases).

QF-PCR detected a trisomy in 6 additional miscarriages with in vitro culture failure. 
Table 1 Incidence and types of chromosome aberrations in spontaneous miscarriages by cytogenetic analysis (CA): new data from the German population and previous results from other studies published since 2000

\begin{tabular}{|c|c|c|c|c|c|c|c|c|c|c|}
\hline Study & $\begin{array}{l}\text { Number } \\
\text { of cases } \\
n\end{array}$ & $\begin{array}{l}\text { No results } \\
\mathrm{n}(\%)\end{array}$ & $\begin{array}{l}\text { Normal } \\
\text { karyotypes } \\
\text { n (\%) }\end{array}$ & $\begin{array}{l}\text { Aberrant } \\
\text { karyotypes } \\
\text { n (\%) }\end{array}$ & $\begin{array}{l}\text { Monosomy X, } \\
\text { Autosomal Monosomy, } \\
\text { Mosaic aneuploidy } \\
\mathrm{n}(\%)\end{array}$ & $\begin{array}{l}\text { Trisomy } \\
\text { (pure) } \\
\mathrm{n}(\%)\end{array}$ & $\begin{array}{l}\text { Triploidy }^{* 1}{ }^{\prime} \\
\text { Tetraploidy }^{* 1}, \\
\text { Polyploidy*1 } \\
\text { n (\%) }\end{array}$ & $\begin{array}{l}\text { Structural } \\
\text { chromosome } \\
\text { aberrations }{ }^{* 1} \\
\text { n (\%) }\end{array}$ & $\begin{array}{l}\text { Multiple } \\
\text { aneuploidies*1 } \\
\text { n (\%) }\end{array}$ & $\begin{array}{l}\text { Others*1 } \\
\mathrm{n}(\%)\end{array}$ \\
\hline Present study & 534 & 144(27) & 153(39) & $237(61)$ & $16(7), 1(<1), 17(7)$ & $111(47)$ & $29(12), 25(10), 54(23)$ & $10(4)^{* 2}$ & $17(7)^{*^{3}}$ & $11(5)$ \\
\hline Gao and coworkers [13] & 100 & $14(14)$ & $37(43)$ & $49(57)$ & $2(4), 1(2), 0$ & $40(82)$ & $3(6), 2(4), 5(10)$ & $1(2)$ & 0 & 0 \\
\hline $\begin{array}{l}\text { Lathi and coworkers } \\
\text { [14] }\end{array}$ & 30 & 0 & 10(33) & $20(67)$ & $0,0,0$ & $14(70)$ & $1(5), 1(5), 2(10)$ & $2(10)$ & $2(10)$ & 0 \\
\hline $\begin{array}{l}\text { Shearer and } \\
\text { coworkers }^{* 3}[6]\end{array}$ & 4,189 & $828(20)$ & $1,627(48)$ & $\begin{array}{l}1,734(52) \\
1,836^{* 4}\end{array}$ & $186(10)^{* 4}, 13(1)^{* 4}, 74(4)^{* 4}$ & $1,074(58)^{* 4}$ & $\begin{array}{l}223(12)^{* 4,5}, 55(3)^{* 4,5}, 278 \\
(15)^{* 4,5}\end{array}$ & $135(7)^{* 4,6}$ & $57(3)^{* 4}$ & $19(1)^{* 4}$ \\
\hline $\begin{array}{l}\text { Menten and coworkers } \\
\text { [15] }\end{array}$ & 100 & $28(28)$ & $55(76)$ & $17(24)$ & $2(12), 0,0$ & 10(59) & $3(18), 0,3(18)$ & $2(12)$ & 0 & 0 \\
\hline $\begin{array}{l}\text { Dória and coworkers } \\
\text { [16] }\end{array}$ & 232 & $59(25)$ & $107(62)$ & $66(38)$ & $5(8), 1(1), 3(5)$ & $33(50)$ & $6(9), 6(9), 12(18)$ & $4(6)$ & $7(11)$ & $1(1)$ \\
\hline $\begin{array}{l}\text { Zhang and coworkers } \\
{[17]}\end{array}$ & 115 & $23(20)$ & $37(40)$ & $\begin{array}{l}55(60) \\
53^{* 7}\end{array}$ & $5(9)^{* 7}, 0,2(4)^{* 7}$ & $36(68)^{* 7}$ & $3(6)^{* 7}, 3(6)^{* 7}, 6(11)^{* 7}$ & $2(4)^{* 7}$ & $2(4)^{* 7}$ & 0 \\
\hline $\begin{array}{l}\text { Robberecht and } \\
\text { coworkers [18] }\end{array}$ & 103 & $26(25)$ & $55(71)$ & $22(29)$ & $3(14), 0,3(14)$ & $7(32)$ & $4(18), 0,4(18)$ & $3(14)$ & $1(4)$ & $1(4)$ \\
\hline $\begin{array}{l}\text { Diego-Alvarez and } \\
\text { coworkers [19] }\end{array}$ & 178 & $76(43)$ & $62(61)$ & 40(39) & $6(15), 0,0$ & $24(60)$ & $3(7), 2(5), 5(12)$ & $1(2)$ & $4(10)$ & 0 \\
\hline $\begin{array}{l}\text { Bruno and coworkers } \\
{[20]}\end{array}$ & 78 & $11(14)$ & $38(57)$ & $29(43)$ & $2(7), 0,1(3)$ & $18(62)$ & $1(3), 0,1(3)$ & $5(17)$ & $1(3)$ & $1(3)$ \\
\hline Hu and coworkers [21] & 38 & $7(18)$ & $15(48)$ & $16(52)$ & $2(12), 0,0$ & $12(75)$ & $2(12), 0,2(12)$ & 0 & 0 & 0 \\
\hline $\begin{array}{l}\text { Menasha and coworkers } \\
\text { [5] }\end{array}$ & 2,180 & $260^{* 8}(12)$ & $821(43)$ & $1,099(57)$ & $96(9), 13(1), 4(1)$ & $721(66)$ & $\begin{array}{l}116(11)^{* 9}, 18(2)^{* 9} \\
152(14)^{* 10}\end{array}$ & $46(4)$ & $67(6)^{* 11}$ & 0 \\
\hline $\begin{array}{l}\text { Sullivan and coworkers } \\
\text { [22] }\end{array}$ & 150 & $17(11)$ & $77(58)$ & $56(42) 55^{* 12}$ & $5(9)^{* 12}, 0,0$ & $35(64)^{* 12}$ & $\begin{array}{l}\text { Not reported, Not } \\
\text { reported, } 12(22)^{* 12}\end{array}$ & $3(5)^{* 12}$ & 0 & 0 \\
\hline $\begin{array}{l}\text { Schaeffer and } \\
\text { coworkers [23] }\end{array}$ & 41 & 0 & $25(61)$ & 16(39) & $1(6), 0,0$ & $14(87)$ & $0,0,0$ & $1(6)$ & 0 & 0 \\
\hline
\end{tabular}


Table 1 Incidence and types of chromosome aberrations in spontaneous miscarriages by cytogenetic analysis (CA): new data from the German population and previous results from other studies published since 2000 (Continued)

\begin{tabular}{|c|c|c|c|c|c|c|c|c|c|c|}
\hline $\begin{array}{l}\text { Jobanputra and } \\
\text { coworkers [24] }\end{array}$ & 57 & $5(9)$ & $22(42)$ & $30(58)$ & $2(7), 1(3), 0$ & $17(57)$ & $4(13), 2(7), 6(20)$ & 0 & $2(7)$ & $2(6)$ \\
\hline $\begin{array}{l}\text { Tabet and coworkers*13 } \\
\text { [25] }\end{array}$ & 21 & 0 & $12(57)$ & $9(43)$ & $1(11)$ & $6(67)$ & $1(11), 0,1(11)$ & $1(11)$ & 0 & 0 \\
\hline $\begin{array}{l}\text { Lomax and coworkers } \\
\text { [26] }\end{array}$ & 301 & $48^{* 13}(16)$ & $98(39)$ & $155(61)$ & $\begin{array}{l}\text { 12(8), Not reported, } \\
\text { Not reported }\end{array}$ & $\begin{array}{l}\text { Aneuploidy } \\
111(72)\end{array}$ & $\begin{array}{l}\text { Not reported, Not } \\
\text { reported, 25(16) }\end{array}$ & $7(4)$ & 0 & 0 \\
\hline Summary & 8447 & $1,546(18)$ & $3,251(47)$ & $\begin{array}{l}3,650(53) \\
3,749(54)\end{array}$ & $\begin{array}{l}346(9)^{* 14}, 30(1)^{* 14} \\
104(3)^{* 14}\end{array}$ & $2,283(61)^{* 14}$ & $\begin{array}{l}399(11)^{* 14}, \\
114(3)^{* 14}, \\
568(15)^{* 14,5,10}\end{array}$ & $223(6)^{* 14}$ & $160(4)^{* 14}$ & $35(1)^{* 14}$ \\
\hline $\begin{array}{l}\text { Goddijn and Leschot } \\
(\text { Review)*15 }\end{array}$ & $\begin{array}{l}\text { Not } \\
\text { reported }\end{array}$ & $\begin{array}{l}\text { Not always } \\
\text { reported }\end{array}$ & $2,377(51)$ & 2,319(49) & $\begin{array}{l}\text { 308(13), Not reported, } \\
\text { Not reported }\end{array}$ & $1,216(52)$ & $\begin{array}{l}\text { Not reported, Not } \\
\text { reported } 481(21)\end{array}$ & $132(6)$ & Not reported & $182(8)^{* 16}$ \\
\hline Variations from (\%) & & $(1-39)$ & & $(38-77)$ & $(2-90)$ & $(33-76)$ & $(8-31)$ & $(2-8)$ & & \\
\hline Eiben and coworkers [4] & 983 & $233(24)$ & $370(49)$ & $380(51)$ & $\begin{array}{l}40(11), \text { Not reported, } \\
\text { Not reported }\end{array}$ & $229(60)$ & $46(12), 32(8), 78(20)$ & $18(5)$ & $11(3)$ & $4(1)$ \\
\hline
\end{tabular}

\section{CA data before 2000 are listed at the end of the table (Goddijn and Leschot, Review [8], Eiben and coworkers [4]).}

${ }^{* 1}$ Mosaicism included.

*2 Single structural chromosome aberrations, all of them were unbalanced, see Table 2.

${ }^{*}$ Shearer and coworkers [6] analysed a total of 5,555 specimens. Unidentified tissue accounted for $25 \%(1,366 / 5,555)$ of their cases, chromosome analysis exclusively in chorionic villi/fetal tissue specimens was successful for $80 \%(3,361 / 4,189)$ of the cases and identified a chromosome aberration (single or more) in $52 \%(1,734 / 3,361)$ of the cases by CA.

*4 The frequencies were calculated from 1,734 chorionic villifetal specimens and from 102 unidentified tissue samples with an aberrant karyotype $(n=1,836)$.

${ }^{*} 5$ Samples included cases with a near-triploidy or near-tetraploidy.

${ }^{*}$ Ninety-one of the 135 cases (67\%) were unbalanced structural chromosome aberrations, 6 of the 135 cases were balanced Robertsonian translocations with a female karyotype and likely represented maternal tissue.

*7The data we have used, are based on 53 cases with a chromosome aberration (see Table 1 in the publication of Zhang and coworkers [17]).

${ }^{* 8}$ Sixty-five of the cases were contaminated and 195 of the cases showed no cell growth.

${ }^{*}$ Samples only included cases with a non-mosaic triploidy or tetraploidy.

${ }^{*}{ }^{*}$ Samples included cases with a non-mosaic and mosaic triploidy or tetraploidy and/or with a near/pseudopolyploid karyotype.

*11 The data we have used, are based on the results from Table 2 in the publication of Menesha and coworkers [5]. The detailed analysis of their cases with multiple aneuploidy is shown in Appendix A and the exact number of multiple aneuploidies is higher $(8 \%, 85 / 1,099)$.

*12The data we have used, are based on 55 cases with a chromosome aberration (see Table 2 in the publication of Sullivan and coworkers [22]).

*13 Fourty-eight samples could not be analysed by both CA and comparative genomic hybridization/flow cytometry.

*14 The frequencies were calculated from 3,749 aberrant karyotypes.

*15 Including the data of Eiben and coworkers [4].

${ }^{* 16}$ Including double and triple trisomies, mosaicism, hydatidiform mola, autosomal monosomy and miscellaneous. 
Table 2 Incidence and types of chromosome aberrations in spontaneous miscarriages by cytogenetic analysis (CA) and by quantitative fluorescent polymerase chain reaction (QF-PCR)

\begin{tabular}{|c|c|c|}
\hline $\begin{array}{l}\text { Type of chromosome aberration by CA } \\
\text { (and QF-PCR) }\end{array}$ & $\begin{array}{l}\text { Number of } \\
\text { patients }\end{array}$ & Structural chromosome aberration (single) $(n=10)$ \\
\hline Monosomy $(n=21)$ & & $46, X, I(Y)(q \mid O)$ \\
\hline $45, x$ & 16 & $\operatorname{mos} 46, X, i(Y)(p 10) / 46, X Y$ \\
\hline Monosomy X (QF-PCR) & 1 & $46, X Y, \operatorname{der}(1) t(1 ; 15)(p 36.1 ; q 22.3) m a t$ \\
\hline $\operatorname{mos} 45, X / 46, X X$ & 2 & $\operatorname{mos} 46, X X, a d d(4)(q ? 31) / 46, X X$ \\
\hline $45, X X,-21$ & 1 & $46, X Y, \operatorname{add}(5)(\mathrm{p} 15.3)$ \\
\hline $\operatorname{mos} 45, X X,-21 / 46, X X$ & 1 & $46, X X, \operatorname{add}(6)(q 21)$ \\
\hline Trisomy $(n=131)$ & & $\operatorname{mos} 47, \mathrm{XY},+\mathrm{i}(12)(\mathrm{p} 10) / 46, \mathrm{XY}$ \\
\hline $47, X X,+2$ & 2 & $46, X X$, add $(14)(p 11.2)$ \\
\hline $\operatorname{mos} 47, X Y,+2 / 46, X Y$ & 1 & $\operatorname{mos} 46, X X, i(20)(q 10) / 46, X X$ \\
\hline $\operatorname{mos} 47, \mathrm{XX},+3 / 46, \mathrm{XX}$ & 1 & $\operatorname{mos} 47, X Y,+m a r / 46, X Y$ \\
\hline $47, X X,+4$ & 3 & Two chromosome aberrations and more $(n=28)$ \\
\hline $\operatorname{mos} 47, X X,+4 / 46, X X$ & 1 & Multiple aneuploidies $(n=17)$ \\
\hline $\operatorname{mos} 47, X X,+5 / 46, X X$ & 1 & $46, X,+21$ \\
\hline $47, X Y,+6$ & 1 & $48, X X Y,+22$ \\
\hline $47, X Y,+7$ & 1 & $48, X X,+2,+22$ \\
\hline $47, X X$ or $47, X Y,+8$ & 5 & $48, X X,+8,+18$ \\
\hline $47, X X$ or $47, X Y,+9$ & 5 & $48, X Y,+9,+15$ \\
\hline $\operatorname{mos} 47, X X,+9 / 46, X X$ & 2 & $48, X Y,+12,+20$ \\
\hline $47, \mathrm{XX}$ or $47, \mathrm{XY},+10$ & 4 & $48, X Y,+13,+21$ \\
\hline $47, X X$ or $47, X Y,+13$ & 6 & $48, X Y,+16,+21$ \\
\hline Trisomy 13 (QF-PCR) & 2 & $48, X X,+16,+22$ \\
\hline $\operatorname{mos} 47, X X,+13 / 46, X X$ & 1 & $49, X Y,+12,+16,+21$ \\
\hline $47, X X$ or $47, X Y,+14$ & 5 & $48, X X,+20,+21$ \\
\hline $\operatorname{mos} 47, X X,+14 / 46, X X$ & 1 & $68, X X Y,-21$ \\
\hline $47, X X$ or $47, X Y,+15$ & 17 & $68, X X X,-22$ \\
\hline $\operatorname{mos} 47, X X,+15 / 46, X X$ & 2 & $94, X X X Y,+7,+7$ \\
\hline $47, X X$ or $47, X Y,+16$ & 22 & $94, X X Y Y,+17,+17$ \\
\hline $\operatorname{mos} 47, X X,+16 / 46, X X$ & 3 & $94, X X Y Y,+20,+20$ \\
\hline $47, X X$ or $47, X Y,+18$ & 8 & $\operatorname{mos} 95, \mathrm{XXYY},+2,+21,+21 / 94, \mathrm{XXYY},+21,+21$ \\
\hline Trisomy 18 (QF-PCR) & 2 & $\begin{array}{l}\text { Structural and/or numerical chromosome aberrations } \\
(\mathrm{n}=11)\end{array}$ \\
\hline $47, X X$ or $47, X Y,+20$ & 2 & $\operatorname{mos} 45, X / 47, X X,+$ mar \\
\hline $47, X X$ or $47, X Y,+21$ & 10 & 46,XX,der(2)t(2;3)(q37;p21),der(3)t(3;9)(p21;q13) \\
\hline Trisomy 21 (QF-PCR) & 2 & $\operatorname{mos} 47, X X,+4 / 47, X X, \operatorname{der}(4) t(4 ; ?)(q 12 ; ?)$ \\
\hline $47, X X$ or $47, X Y,+22$ & 20 & $47, X Y, t(5 ; 5)(p 10 ; p 10),+5$ \\
\hline $\begin{array}{l}\operatorname{mos} 47, X X,+22 / 46, X X \\
\text { Triploidy }(\mathbf{n}=\mathbf{3 0})\end{array}$ & 1 & $\begin{array}{l}\operatorname{mos} 46, X Y, \operatorname{der}(5) t(5 ; 14)(q 23 ; q 11.2),+5,-4 / 45, X Y, \text { der } \\
(13 ; 14)(p 10 ; q 10) / 46, X Y\end{array}$ \\
\hline $69, X X X$ or $69, X X Y$ & 29 & mos 46,XX,del(8)(p10)/46,XX,i(8)(q10) \\
\hline Triploidy (QF-PCR) & 1 & $47, X Y, t(9 ; 13)(p 22 ; q 14.1),+13$ \\
\hline Tetraploidy $(n=25)$ & & $46, X X, \operatorname{der}(14 ; 15)(q 10 ; q 10),+14$ \\
\hline $92, X X X X$ or $92, X X Y Y$ & 5 & $47, X X, \operatorname{der}(15) t(3 ; 15)(p 10 ; q 10),+21$ \\
\hline $\operatorname{mos} 92, X X X X$ or $92, X X Y Y / 46, X Y$ & 20 & $91, X X,-3,+5,-6, t(8 ; 19)(q 22 ; q 13.1)$ \\
\hline
\end{tabular}
and by quantitative fluorescent polymerase chain reaction (QF-PCR) (Continued)

Structural chromosome aberration (single) $(n=10)$

Table 2 Incidence and types of chromosome aberrations in spontaneous miscarriages by cytogenetic analysis (CA)

\section{1} 1

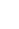
1 1

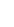


Table 2 Incidence and types of chromosome aberrations in spontaneous miscarriages by cytogenetic analysis (CA) and by quantitative fluorescent polymerase chain reaction (QF-PCR) (Continued)

\begin{tabular}{ll}
\hline mos 94,XXXX, + mar1 $\times 2 / 47, X X,+$ mar1/46,XX & 1 \\
Chromosome aberrations by CA & $\mathbf{2 3 7 / 3 9 0 , ( 6 1 \% )}$ \\
Chromosome aberrations by QF-PCR & $\mathbf{8}$ \\
Chromosome aberrations by CA and QF-PCR & $\mathbf{2 4 5 / 4 1 7 , ( 5 9 \% )}$ \\
\hline
\end{tabular}

\section{Monosomy}

$C A(n=20)$

Monosomy accounted for $8 \%$ of the aberrant karyotypes $(20 / 237)$. Monosomy X was found in $90 \%(18 / 20)$ of the monosomies. Of them, $11 \%(2 / 18)$ showed gonosomal mosaicism 45,X/46,XX. Monosomy 21 accounted for $10 \%$ $(2 / 20)$ of the monosomies. Of them, one case showed a monosomy 21 mosaicism.

QF-PCR detected a monosomy $\mathrm{X}$ in one miscarriage with in vitro culture failure.

\section{Triploidy and Tetraploidy CA (Triploidy $n=29$, Tetraploidy $n=25$ )}

Triploidy accounted for $12 \%(29 / 237)$ of the aberrant karyotypes. Mosaicism was not observed. Tetraploidy accounted for $10 \%(25 / 237)$ of the aberrant karyotypes. Of them, $80 \%(20 / 25)$ showed a tetraploidy mosaicism.

QF-PCR detected a triploidy in one additional miscarriage with in vitro culture failure.

\section{Structural chromosome aberrations (single) $(n=10)$}

Single structural chromosome aberrations accounted for $4 \%(10 / 237)$ of the aberrant karyotypes, all of them showed an unbalanced chromosome aberration. Fifty percent of the chromosomally unbalanced cases showed mosaicism.

\section{Multiple aneuploidies $(n=17)$}

Multiple aneuploidies accounted for 7\% (17/237) of the aberrant karyotypes. Of them, 53\% (9/17) of the cases carried a double trisomy and 6\% (1/17) of the cases showed a triple trisomy. There was one case $(6 \%, 1 / 17)$ of combined trisomy 21 and monosomy X. Six cases (35\%, 6/17) showed a near-triploid or near-tetraploid karyotype. Gain or loss of chromosome 21 was found most frequently (7 cases), followed by chromosome 22 ( 4 cases) and chromosome 16 (3 cases).

Others $(n=11)$

These samples displayed a wide variety of numerical and/or structural chromosome aberrations and accounted for $5 \%(11 / 237)$ of the aberrant karyotypes. Nine cases showed double structural chromosome aberrations (derivative chromosome, translocation, deletion and isochromosome) or a single structural chromosome aberration together with one or two aneuploidies. A near-tetraploid karyotype was found in two further cases, one of them with the gain of chromosome 5 and the loss of chromosomes 3 and 6 together with a reciprocal translocation and the other with the gain of two copies of the same marker chromosome together with a 47,XX,+mar/46,XX mosaicism.

\section{Discussion}

In the present study the overall male-to-female sex ratio among the normal karyotypes was 0.94 in chorionic villi. A consistent feature during the large German study of Eiben and coworkers [4] was the excess of females in chromosomally normal spontaneous miscarriages (maleto-female ratio of 0.71 ). Using a nearly direct-preparation CA method of chorionic villi after short culture of approximately 24 hours, their unbalanced rate cannot be explained by maternal contamination. The results of Eiben and coworkers [4] provide the evidence for a female-specific developmental disadvantage at early stage of embryonic development, probably because they analysed most of the spontaneous miscarriages between weeks 5 and 13 of gestation age. We, however, cultivated the chorionic villi for a longer time, after surgical evacuation between weeks 7 and 34 of gestation age. Without any clinical data, we could not separate our spontaneous miscarriage results between early or late gestation age. However, in a study approximately similarly designed to our investigation, Shearer and coworkers [6] observed a remarkably constant sex ratio of 1.0 both by culturing of chorionic villi and by FISH after direct cell preparation of the same tissue type. Based on these data we can suspect that our nearly balanced male-to-female sex ratio in pregnancies without a chromosome aberration indicated that the majority of analysed chorionic villi after careful dissection was not contaminated with maternal cells.

The results of the present retrospective large German study and of other foreign spontaneous miscarriage studies since 2000 reviewed and pooled in Table 1 give one of the most comprehensive indications of the incidence and types of chromosome aberrations by CA observed to date in spontaneous miscarriages. In our German spontaneous miscarriage group the frequency of $61 \%$ of cases with a chromosome aberration detected by $\mathrm{CA}$ is comparable with the results of both large foreign studies $[5,6]$ after karyotyping 5,383 spontaneous miscarriages overall. They found a frequency of chromosome aberrations ranging from $52 \%$ to $57 \%$. In both studies CA was exclusively done after tissue culturing and gestation age at the time of abortion was unknown, so that their data compare well with our results. In the single large German study in 1990 a low frequency of $51 \%$ of chromosome aberrations in 750 karyotyped spontaneous miscarriages was reported [4]. 
However, the proportions of chromosome aberrations among the different spontaneous miscarriage studies always varied extremely. The review in 2000 of Goddijn and Leschot [8] reported an average frequency of chromosome aberrations of $49 \%$ in 4,696 karyotyped cases, which is comparable with the pooled data in 2014 with an average frequency of chromosome aberrations of $54 \%$ in 7,000 karyotyped spontaneous miscarriages (Table 1).

At any time, autosomal pure and mosaic trisomies comprise the largest single class of chromosome aberrations in spontaneous miscarriages with trisomy 16 as the most common trisomy $[5,6,8]$. Also in our study, trisomy 16 was the most frequently represented, accounting for $20 \%$ of all trisomies, followed by trisomy $22(17 \%)$, trisomy $15(15 \%)$ and trisomy 21 (8\%). Including the cases with multiple aneuploidies, we observed nearly each autosomal trisomy, with the exception of trisomy 1 , trisomy 11, and trisomy 19. In the large foreign investigation of Shearer and coworkers [6], only trisomy 1 was missed in 1,836 cytogenetic aberrant spontaneous miscarriages and in a similar study of Menasha and coworkers [5] trisomy 1 and trisomy 19 were the least common, with only one case of each found in 1,099 aberrant karyotypes. The reason why certain types of chromosome aberrations are infrequent is unknown. However, chromosome 1 and chromosome 11 are gene-dense [27,28] and chromosome 19 has the highest gene density of all human chromosomes [29]. Therefore trisomy of these chromosomes may be responsible for very early pregnancy loss.

Pure or mosaic monosomy $\mathrm{X}$ was always the predominant gonosomal aberration in all spontaneous miscarriage studies before and after 2000. Autosomal monosomies in spontaneous miscarriages are usually rare. Of the pooled cytogenetic results of 4,696 spontaneous miscarriages only five autosomal monosomies $(0.2 \%)$ were reported per 2,319 aberrant karyotypes before 2000 [8]. In our study, we only observed two cases with monosomy 21 (0.8\%). Monosomy 21 was also the most common autosomal monosomy in both large foreign studies published recently $[5,6]$. Shearer and coworkers [6] additionally observed one case with monosomy 13 and one case with monosomy 15 in 1,836 aberrant karyotyped samples.

Triploidy is not uncommon in early pregnancies $(1 \%$ $3 \%$ of recognized conceptions), but about $>99 \%$ are lost during the first or second trimester. Of all 16-week pregnancies, only 1 in 30,000 is estimated to be triploid [30]. Surprisingly, Wick and coworkers [31] detected four cases of second-trimester triploidy (all patients were at least 19 weeks' gestation) which were diagnosed at a tertiary centre within a 1-year period, so that some of the triploid karyotypes survived longer. Generally a high rate of triploidy has been observed in spontaneous miscarriages by CA. The frequency of $12 \%$ in the present study directly corresponds to the frequencies of other past large reports [4-6].

The tetraploidy rate of $10 \%$ in the present study is higher than the average frequency of tetraploidy of $3 \%$ in pooled data from 7,000 cytogenetically analysed spontaneous miscarriages (Table 1 ). If we only calculate our results with pure tetraploidy, the frequency would be $2.1 \%$, which is in the range of other recent large studies $[5,6]$. Therefore, in the present study a cultural artifact in cases with tetraploidy mosaicism cannot be entirely excluded. However, it should be mentioned that Eiben and coworkers [4] reported a frequency of $8 \%$ of cases with a tetraploidy in the German spontaneous miscarriage group after nearly direct-preparation of chorionic villi with a rate of pure tetraploidy of $2.3 \%$, which is in concordance with our results. In addition, because also their mosaic cases were classified independently by chorionic villi histology as being chromosomally abnormal Eiben and coworkers [4] assumed that a significant number of early spontaneous miscarriages might result from a disordered placental development characterized by chorionic mosaicism with diploid and tetraploid cells detectable only by their nearly direct-preparation technique. Possibly this phenomenon is detectable even after prolonged cultivation of chorionic villi. This would explain the high rate of mosaic tetraploidy cases in the present study.

In our spontaneous miscarriage group 7\% (17/237) of all aberrant karyotypes carried a multiple aneuploidy. It is of interest that 15 out of the 17 affected patients were from age 35 to age 48, implying a direct correlation between increased maternal age with increased risk of non-disjunction of chromosomes. The collection of 85 multiple aneuploid karyotypes in 1,099 aberrant spontaneous miscarriages (8\%) in the investigation of Menasha and coworkers [5] is the largest study published to date. These karyotypes were also detected predominantly in older women. The average frequency of multiple aneuploidies calculated from a pooled 3,749 aberrrant karyotypes obtained from conventional tissue culture is somewhat lower (4\%, Table 1) and similar to the frequency (3\%) of the past large German study of Eiben and coworkers [4] using a nearly direct-preparation CA method of chorionic villi. This reflects once more the apparent similarity between both culture techniques of chorionic villi or other heterogeneous tissues cultured from an aborted foetus.

The frequency of structural chromosome aberrations in spontaneous miscarriages seems to be extremely constant over many years. The pooled average frequencies of structural chromosome aberrations before 2000 and from 2000 to 2014 were $6 \%$ [8, Table 1]. In the present study, non-mosaic cases with a structural chromosome aberration, which could be inherited, occurred in 5\% 
$(11 / 237)$ of the aberrant karyotypes (Table 2). This frequency is the range of the reported frequency of $4 \%$ of unbalanced chromosome aberrations due to a translocation $(n=15)$ in the large German study in 1990 [4].

Although CA of spontaneous miscarriages is highly recommended, CA studies entail certain problems such as culture failure (Table 1). To overcome this problem, alternative techniques complementary to CA have been used for genetic testing of miscarriage samples, including fluorescence in situ hybridization (FISH), multiplex ligation-dependent probe amplification (MLPA) and QFPCR [32]. In the present study, one hundred and fortyfour spontaneous miscarriages (27\%) failed to grow in vitro. As a supplementary method, we used QF-PCR to improve our success rate in the detection of clinically relevant chromosome aberrations. A total of 27 samples with culture failure were analysed by molecular analysis on demand. QF-PCR for chromosomes 13, 18, 21, X and $\mathrm{Y}$ was informative in all these cases and detected a chromosome aberration in a further 8 spontaneous miscarriages.

\section{Conclusion}

By generating an overview of the genetic aspects of spontaneous and recurrent abortions, Van den Berg and coworkers [32] reported that more chromosome aberrations were detected by CA compared to FISH or MLPA or QF-PCR. Newer techniques such as array-comparative genome hybridization (array-CGH) or CGH are useful in detecting deletions and duplications including submicroscopic imbalances in spontaneous abortions, but they are unable to detect the ploidy status and low level mosaicism $[32,33]$. By using these techniques independently, instead of $\mathrm{CA}$, they unfortunately showed no added clinical value [32]. Therefore, CA is still the gold standard in the detection of chromosome aberrations in spontaneous miscarriages until further work is done before the absolute detection rate can be answered with newer techniques. In our German retrospective large study, the incidence and types of chromosome aberrations by $\mathrm{CA}$ are within the reported range of other studies published previously before and after 2000. Therefore, we can conclude that cytogenetic aspects of spontaneous miscarriages have not changed over the years. Thereby, in our laboratory, QF-PCR played an important role as a supplementary test when culture failure occurred and improved our success rate in the detection of clinically relevant chromosome aberrations.

\section{Competing interests}

The author declares that she has no competing interests.

\section{Acknowledgements}

J. Jenderny would like to thank W. Schmidt for the final reports of the first QF-PCR analyses and R. Thede, C. Goldmann and M. Ebrecht for their help in setting up the laboratory experiments. Finally, J. Jenderny would like to thank the many patients and all of the gynaecologists who participated in these studies.

Received: 12 March 2014 Accepted: 27 May 2014

Published: 5 June 2014

References

1. Gilmore $\mathrm{DH}, \mathrm{McNay}$ MB: Spontaneous fetal loss rate in early pregnancy. Lancet 1985, 12:107.

2. Mills JL, Simpson JL, Driscoll SG, Jovanovic-Peterson L, Van Allen M, Aarons $J$ H, Metzger B, Bieber FR, Knopp RH, Holmes LB, Petersen CM, WithiamWilson M, Brown Z, Ober C, Harley E, Macpherson TA, Duckles A, MuellerHeubach E: Incidence of spontaneous abortion among normal women and insulin-dependent diabetic women whose pregnancies were identified within 21 days of conception. N Engl J Med 1988, 22:1617-1623.

3. Wilcox AJ, Weinberg CR, O'Connor JF, Baird DD, Schlatterer JP, Canfield RE, Armstrong EG, Nisula BC: Incidence of early loss of pregnancy. N Engl J Med 1988, 319:189-194.

4. Eiben B, Bartels I, Bähr-Porsch S, Borgmann S, Gatz G, Gellert G, Goebel R, Hammans W, Hentemann M, Osmers R, Rauskolb R, Hansmann I: Cytogenetic analysis of 750 spontaneous abortions with the directpreparation method of chorionic villi and its implications for studying genetic causes of pregnancy wastage. Am J Hum Genet 1990, 47:656-663.

5. Menasha J, Levy B, Hirschhorn K, Kardon NB: Incidence and spectrum of chromosome abnormalities in spontaneous abortions: New insights from a 12-year study. Genet Med 2005, 7:251-263.

6. Shearer BM, Thorland EC, Carlson AW, Jalal SM, Ketterling RP: Reflex fluorescent in situ hybridization testing for unsuccessful product of conception cultures: a retrospective analysis of 5555 samples attempted by conventional cytogenetics and fluorescent in situ hybridization. Genet Med 2011, 13:545-552.

7. Carp H, Toder V, Aviram A, Daniely M, Mashiach S, Barkai G: Karyotype of the abortus in recurrent miscarriage. Fertil Steril 2001, 75:678-682.

8. Goddijn M, Leschot NJ: Genetic aspects of miscarriage. Baillieres Best Pract Res Clin Obstet Gynaecol 2000, 14:855-865. Review.

9. Schmidt W, Jenderny J, Hecher K, Hackelöer BJ, Kerber S, Kochhan L, Held KR: Detection of aneuploidy in chromosomes $X, Y, 13,18$ and 21 by QF-PCR in 662 selected pregnancies at risk. Mol Hum Reprod 2000, 6:855-860.

10. Jenderny J, Schmidt W, Hecher K, Hackelöer BJ, Kerber S, Kochhan L, Held KR: Increased nuchal translucency, hydrops fetalis or hygroma colli. A new test strategy for early fetal aneuploidy detection. Fetal Diagn Ther 2001, 16:211-214.

11. Jenderny J, Schmidt W, Kochhan L: Chromosome aberrations identified by cytogenetic analysis of the first 2 clones of cultured amniotic fluid cells compared with QF-PCR results. Cytogenet Genome Res 2014, 16:239-244 [Epub ahead of print].

12. Shaffer LG, McGowan-Jordan J, Schmidt M: ISCN 2013 An International System for Human Cytogenetic Nomenclature. Basel: Karger Verlag AG; 2013.

13. Gao J, Liu C, Yao F, Hao N, Zhou J, Zhou Q, Zhang L, Liu X, Bian X, Liu J: Arraybased comparative genomic hybridization is more informative than conventional karyotyping and fluorescence in situ hybridization in the analysis of first-trimester spontaneous abortion. Mol Cytogenet 2012, 5:33.

14. Lathi RB, Massie JA, Loring M, Demko ZP, Johnson D, Sigurjonsson S, Gemelos G, Rabinowitz M: Informatics enhanced SNP microarray analysis of 30 miscarriage samples compared to routine cytogenetics. PLoS One 2012, 7:3.

15. Menten B, Swerts K, Delle Chiaie B, Janssens S, Buysse K, Philippé J, Speleman F: Array comparative genomic hybridization and flow cytometry analysis of spontaneous abortions and mors in utero samples. BMC Med Genet 2009, 10:89.

16. Dória S, Carvalho F, Ramalho C, Lima V, Francisco T, Machado AP, Brandão O, Sousa M, Matias A, Barros A: An efficient protocol for the detection of chromosomal abnormalities in spontaneous miscarriages or foetal deaths. Eur J Obstet Gynecol Reprod Biol 2009, 147:144-150.

17. Zhang YX, Zhang YP, Gu Y, Guan FJ, Li SL, Xie JS, Shen Y, Wu BL, Ju W Jenkins EC, Brown WT, Zhong N: Genetic analysis of first-trimester miscarriages with a combination of cytogenetic karyotyping, microsatellite genotyping and array CGH. Clin Genet 2009, 75:133-140.

18. Robberecht C, Schuddinck V, Fryns JP, Vermeesch JR: Diagnosis of miscarriages by molecular karyotyping: benefits and pitfalls. Genet Med 2009, 11:646-654. 
19. Diego-Alvarez D, Rodriguez De Alba M, Cardero-Merlo R, Diaz-Recasens J, Ayuso C, Ramos C, Lorda-Sanchez I: MLPA as a screening method of aneuploidy and unbalanced chromosomal rearrangements in spontaneous miscarriages. Prenat Diagn 2007, 27:765-771.

20. Bruno DL, Burgess T, Ren H, Nouri S, Pertile MD, Francis DI, Norris F, Kenney BK, Schouten J, Andy Choo KH, Slater HR: High-throughput analysis of chromosome abnormality in spontaneous miscarriage using an MLPA subtelomere assay with an ancillary FISH test for polyploidy. Am J Med Genet A 2006, 140:2786-2793.

21. Hu Y, Chen X, Chen LL, Xu ZF, Wang X, Cui H: Comparative genomic hybridization analysis of spontaneous abortion. Int I Gynaecol Obstet 2006, 92:52-57.

22. Sullivan AE, Silver RM, LaCoursiere DY, Porter TF, Branch DW: Recurrent fetal aneuploidy and recurrent miscarriage. Obstet Gynecol 2004, 104:784-788.

23. Schaeffer AJ, Chung J, Heretis K, Wong A, Ledbetter DH, Lese Martin C: Comparative genomic hybridization-array analysis enhances the detection of aneuploidies and submicroscopic imbalances in spontaneous miscarriages. Am J Hum Genet 2004, 74:1168-1174.

24. Jobanputra V, Sobrino A, Kinney A, Kline J, Warburton D: Multiplex interphase FISH as a screen for common aneuploidies in spontaneous abortions. Hum Reprod 2002, 17:1166-1170.

25. Tabet AC, Aboura A, Dauge MC, Audibert F, Coulomb A, Batallan A, Couturier-Turpin MH, Feldmann G, Tachdjian G: Cytogenetic analysis of trophoblasts by comparative genomic hybridization in embryo-fetal development anomalies. Prenat Diagn 2001, 21:613-618.

26. Lomax B, Tang S, Separovic E, Phillips D, Hillard E, Thomson T, Kalousek DK Comparative genomic hybridization in combination with flow cytometry improves results of cytogenetic analysis of spontaneous abortions. Am J Hum Genet 2000, 66:1516-1521.

27. Gregory SG, Barlow KF, McLay KE, Kaul R, Swarbreck D, Dunham A, Scott CE, Howe KL, Woodfine K, Spencer CC, Jones MC, Gillson C, Searle S, Zhou Y, Kokocinski F, McDonald L, Evans R, Phillips K, Atkinson A, Cooper R, Jones C, Hall RE, Andrews TD, Lloyd C, Ainscough R, Almeida JP, Ambrose KD, Anderson F, Andrew RW, Ashwell Rl, et al: The DNA sequence and biological annotation of human chromosome 1. Nature 2006, 441:315-321.

28. Taylor TD, Noguchi H, Totoki Y, Toyoda A, Kuroki Y, Dewar K, Lloyd C, Itoh T, Takeda T, Kim DW, She X, Barlow KF, Bloom T, Bruford E, Chang JL, Cuomo CA, Eichler E, FitzGerald MG, Jaffe DB, LaButti K, Nicol R, Park HS, Seaman C, Sougnez C, Yang X, Zimmer AR, Zody MC, Birren BW, Nusbaum C, Fujiyama $A$, et al: Human chromosome 11 DNA sequence and analysis including novel gene identification. Nature 2006, 440:497-500.

29. Grimwood J, Gordon LA, Olsen A, Terry A, Schmutz J, Lamerdin J, Hellsten U, Goodstein D, Couronne O, Tran-Gyamfi M, Aerts A, Altherr M, Ashworth L, Bajorek E, Black S, Branscomb E, Caenepeel S, Carrano A, Caoile C, Chan YM, Christensen M, Cleland CA, Copeland A, Dalin E, Dehal P, Denys M, Detter JC, Escobar J, Flowers D, Fotopulos D, et al: The DNA sequence and biology of human chromosome 19. Nature 2004, 428:529-535.

30. McKinlay Gardner RJ, Sutherland GR: Down syndrome, other full aneuploidies, and polyploidy. In Chromosome abnormalities and genetic counseling. 3rd edition. Edited by McKinlay Garner RJ, Sutherland GR. New York: Oxford University Press; 2004:249-263.

31. Wick JB, Johnson KJ, O'Brien J, Wick MJ: Second-trimester diagnosis of triploidy: a series of four cases. AJP Rep 2013, 3:37-40

32. Van den Berg MM, Van Maarle MC, Van Wely M, Goddijn M: Genetics of early miscarriage. Biochim Biophys Acta 2012, 1822:1951-1959. Review.

33. Valli R, Marletta C, Pressato B, Montalbano G, Lo Curto F, Pasquali F, Maserati E: Comparative genomic hybridization on microarray (a-CGH) in constitutional and acquired mosaicism may detect as low as $8 \%$ abnormal cells. Mol Cytogenet 2011, 4:13.

doi:10.1186/1755-8166-7-38

Cite this article as: Jenderny: Chromosome aberrations in a large series of spontaneous miscarriages in the German population and review of the literature. Molecular Cytogenetics 2014 7:38.

\section{Submit your next manuscript to BioMed Central and take full advantage of:}

- Convenient online submission

- Thorough peer review

- No space constraints or color figure charges

- Immediate publication on acceptance

- Inclusion in PubMed, CAS, Scopus and Google Scholar

- Research which is freely available for redistribution

Submit your manuscript at www.biomedcentral.com/submit
() Biomed Central 